\title{
Assessment of Vegetation Structural Diversity And Similarity Index of IITA Forest Reserve in Ibadan, Oyo State, Nigeria
}

\author{
Ariyo, O.C. ${ }^{1 *}$, Oluwalana. S.A. ${ }^{2}$, Faleyimu, $0 . .^{3}$ and Ariyo, M.O. ${ }^{1}$ \\ ${ }^{1}$ Department of Agricultural Extension Management, Federal College of Forestry Mechanization, \\ Kaduna, Nigeria \\ ${ }^{2}$ Department of Forestry and Wild Life Management, University of Agriculture, Abeokuta, Ogun State, \\ Nigeria. \\ ${ }^{3}$ Department of Biological Sciences, Ondo State University of Science \& Technology, Okitipupa, Ondo \\ State Nigeria \\ *Corresponding author: ask4ariyo@yahoo.com +2348033931981
}

\begin{abstract}
The analysis of vegetation structural diversity and similarity index of International Institute of Tropical Agriculture (IITA) forest reserve was carried out by vegetation survey using transects and plot sampling techniques. Forty plots of $10 \mathrm{~m}$ by $10 \mathrm{~m}$ each were laid equally along four transect $\left(A, B, C\right.$, at $90^{\circ} \mathrm{E}$ and $D$ at $\left.0^{\circ} \mathrm{N}\right)$. Data were analysed using descriptive statistics, relative density, diversity and similarity indices. The result showed that the forest reserve has one hundred and ninety species of plants belonging to sixty three families. The dominant plant families recorded in the forest are Leguminosae (12.63\%), Rubiaceae (8.42\%), Euphorbiaceae (7.89\%), Apocynaceae (5.26\%) and Sterculiaceae (3.68\%). The most abundant plant species in the forest are mostly secondary colonizers climbers, shrubs and trees such as Culcasia saxatilis (4.46\%), Icacina trichantha (4.10\%), Shrub: Alchornea laxiflora (3.86\%), Sphenocentrum jollyanum (3.50\%), followed by tree: Newbouldia laevis (3.23\%), and Funtumia elastica (2.63\%) respectively. Transect $D$ had the highest Simpson's diversity index of 0.01184 while the lowest is with $C$ 0.02091. The Simpson similarities indices (Beta diversity) of transects varied from $50.75 \%$ to $42.76 \%$ for transects $B$ and $C, A$ and $C$, and $C$ and $D$ respectively. The forest reserve of IITA shows a high diversity (alpha, gamma and beta diversity) of plants and have multiplicity of species, therefore, adequate protection of the reserve should be a priority to maintain and prevent loss of plant biodiversity.
\end{abstract}

Keywords: Vegetation, structural diversity, IITA forest reserve, plant biodiversity, Simpson's diversity index

\section{INTRODUCTION}

Tropical forests are among the richest and most complex terrestrial ecosystems supporting a variety of life forms of not less than half of all species on earth (Phillips, 1996) and a tremendous intrinsic ability for selfregeneration if properly maintained. The rate of deforestation has been estimated variously for different parts of the world. It has been postulated that forests have been recently affected by large scale anthropogenic and natural changes (Philips, 1996) and better understanding of the ecological changes in 
natural forest depends on progress in monitoring network of tropical forest plots.

Nigeria embraces a very wide range of habitat and ecosystem with varying degrees of species diversity within them. Some ecosystems are impoverished relative to their recent past and the diversity of species is greatly depleted in certain areas. Species' diversities within habitats vary greatly and they are higher in low land equatorial rain forest. In general, species' diversity is well correlated with the annual amount of rainfall with the wetter areas tending to be richer in species diversity in the southern parts of Nigeria (Ayodele and Lameed 1999). "Biodiversity is the totality of heritable variations or differences in characteristics that exist in all living things, individuals and their species in various ecosystems in different parts of the earth" (Ayodele and Lameed, 1999). "Biodiversity includes genetic diversity, species richness and ecosystem diversity, and assumes that these are interdependent" (Groombridge and Jenkins, 2002) "and quantified through taxonomy inventories within specified areas" (Fox and Rowntree, 2000). "The number of different species within a geographical area depends on migration and adaptation to environmental conditions and how they in turn modify the environment" (Groves, 2002).

Saye and Wegge (1992) reported that the loss and fragmentation of tropical moist forest is the single threat to the world's biological diversity. According to Kokwaro (1994), seventeen million hectares of tropical forest are being cleared annually, and scientists therefore believe that about sixty thousand of the world's two hundred and forty thousand plant species and even higher proportions of vertebrates and insects species could become extinct during the next three decades unless deforestation trend is slowed down immediately. Increased human population led to forest clearings for agriculture, firewood collection and charcoal production and hence posed a threat to sustainable biodiversity conservation (Mogaka, 2002). In Nigeria, the situation is worse as biodiversity is adversely under serious threat because of lack of implementation of policies and law of conservation, economic instability, poverty and low standard of living of the people.

Measurement of structural diversity appears a good indicator of forest management (Lindgren and Sullivan, 2001). In fact, structural diversity has been reported to be a major factor determining forest vegetation (Koop, 1989). Generally, biodiversity measurement typically focuses on the species' level and species' diversity is one of the most important indices which are used for the evaluation of ecosystems at different scales (Ardakani, 2004). Diversity is always measured in units of the number of species (Jost, 2006). Beta diversity is generally thought of as the change in diversity among various Alpha diversities (variation in species composition among geographic regions) (Magurran, 2004). There exists a wide variety of methods for measuring Beta diversity, among which similarity measures are the simplest and the most commonly used for calculating Beta diversity from abundance or presence/absence data (Koleff et al., 2003). Both diversity and similarity indices can be used to compare differences between communities or samples from communities (Koleff et al., 2003, Magurran, 2004). Sorensen (1948) index was based on both the number of species present in samples and the numbers only seen in each of them (Koleff et al., 2003). Sorenson's measure is regarded as one of the most effective presence/absence similarity 
measures (Sorensen, 1948). Lennon et al. (2001) noted that if samples differ greatly in terms of their species richness, Sorenson measures will always be large.

The International Institute of Tropical Agriculture (IITA) forest reserve is a mosaic of abandoned villages and farmland at various stages of forest re-growth. The plots that were under cultivation before the acquisition forty years ago are now mainly a thicket of Chromolaena odorata. It is interesting that although some tree saplings are now emerging through this undergrowth, there is so far little sign of the structure and diversity of the original primary forest. On the other hand, it is remarkable to note that many of the forest species of plants and animals have managed to survive or even flourish in this extended "bush fallow". The natural vegetation in this area could be classified as tropical semi-deciduous forest with various pockets of vegetation types ranging from derived savanna, secondary forest and riparian types. According to Ezealor (2002), the area resembles mature Guinea-Congo lowland rainforest with scattered emergence of trees which include Ceiba, Milicia and Terminalia species. Large clumps of bamboo (Bambusa vulgaris) are common; stands of Raphia vinifera are found along watercourses while scattered oil-palms Elaeis guineensis grow in both low-lying and the relatively better-drained upland areas. The reserve had been under active protection as an informal forest and nature reserve for forty years, therefore, it is important to assess the vegetation structural diversity and similarity index in order to know species composition and structure of the forest reserve.

\section{METHODOLOGY}

The study area: The study area is International Institute of Tropical Agriculture (IITA) reserve forest, Ibadan, Oyo State, Nigeria. IITA is located at longitude $7^{\circ} 30^{\prime} 8^{\prime \prime} \mathrm{N}$, latitude $3^{\circ} 54^{\prime} 37^{\prime \prime} \mathrm{E}$ and $243 \mathrm{~m}$ above sea level (Tenkouano and Baiyeri, 2007). The site falls within humid tropical lowland region with two distinct seasons: the longer wet season and shorter dry season. The wet season lasts for eight months and it extends from March to October while the dry season lasts for four months from November to February. The rainfall pattern is bimodal with an annual total which ranges from 1,300-1,500mm most of which falls between May and September. The average daily temperature ranges between $21^{\circ} \mathrm{C}$ and $23^{\circ} \mathrm{C}$ while the maximum is between $28^{\circ} \mathrm{C}$ and $34^{\circ} \mathrm{C}$. Radiation is about $5285 \mathrm{MJ} / \mathrm{m}^{2} /$ year. Mean relative humidity is in the range of $64 \%$ to $83 \%$ ((Tenkouano and Baiyeri, 2007).

\section{Methods of data collection}

The method of data collection for this study was based on vegetation survey using transects and plot sampling techniques (Wolda, 1983).

Vegetation Transect: The vegetation transects was established to obtain a representative sample of the woody vegetation of the study area as well as to understand the species assemblage of trees, shrubs and climbers in their various habitats (forest composition) at the beginning of the study (base line data). Transects were established with minimal disruption to the environment and marked with flagging tape at every $10 \mathrm{~m}$. 
Transects and plots designs: Four transects $\left(A, B, C 90^{\circ} E\right.$ and $\left.D 0^{\circ} N\right)$ were constructed with the aid of prismatic compass within the reserved area. Each transect is $500 \mathrm{~m}$ long. Ten sampling plots of $10 \mathrm{~m}$ by $10 \mathrm{~m}$ each were demarcated along each of the transect (using ranging poles, compass and red flag tape) making a total number of 40 sampling plots ( 4 transects by 10 plots). A distance of $40 \mathrm{~m}$ was left between each of the plot to minimize repetition of plant species while $20 \mathrm{~m}$ was left at the beginning and at the end of each transect as the border row to minimize edge effects. Complete enumeration and identification of herbs, climbers, shrubs and trees was carried out in each of the plot with their proper scientific names and vernacular names. Scientific names are important in ecological studies while vernacular names were useful for ethno botanical studies. Samples of plants that cannot be identified on the field were taken to the Arboretum of Forestry Research Institute of Nigeria, Ibadan for proper identification.

\section{Data analysis}

The data were analyzed using descriptive statistics. Diversity indices and similarities indices were also used.

Diversity indices: Diversity indices used by ecologists have been applied in quantitative ethnobotany (Begossi 1996; Figueiredo, et al., 1993, 1997). It is the variety and variability among living organism, it measures both species' richness (measure of abundance) and the equitability with which individuals are distributed among the species (Isichei, 1996; Badejo, 1996). Three levels of diversities have been distinguished. These are alpha, beta and gamma diversities (Ojo, 1996; Gauch, 1986). Community studies vary in the number of species encountered in a sample (alpha diversity), and in the total number of species encountered in a study (gamma diversity)(Gauch, 1986). For the measurement of diversity, the Alpha (Simpson diversity index), and Beta (Sorensen similarities indices) diversity were used to determine and compare the plant diversity of each transect.

Alpha Diversity: - Two common approaches for measuring alpha diversity are species' richness (number of species in the community) and evenness and heterogeneity (distribution of individual among the species). The common index for Simpson diversity index was used (Simpson, 1949).

\footnotetext{
Simpson's diversity index (D) $=\sum n_{i}\left(n_{i}-1\right) / N(N-1)$ Where

$\mathrm{N}=$ Total frequency of all the species

$\mathrm{n}=$ Total number of each species
}

Similarity indices (Beta Diversity): - The measurement can either be in terms of comparing differences or similarity between samples or location. Wolda (1983) suggested the use of similarity indices for measuring beta diversity. Sorensen similarities index was therefore used to determine and compare the similarities of plant species in transect $A \& B, A \& C, A \& D, B \& C, B \& D$, and $C \& D$ because the plots and transects are of equal sizes (Sorensen, 1948) 


\section{Sorensen similarity index $=a / a+b+c * 100$}

$a=$ number of species common to both sites (e.g. transect $A \& B$ )

$b=$ number of species in site $A$ not in site $B$ (e.g. species in transect $A$ not in transect $B$ ).

$c=$ number of species in site $B$ not in site $A$ (e.g. species in transect $B$ not in transect $A$ ).

\section{Vegetation Survey}

\section{RESULTS}

One hundred and ninety species of plants belonging to sixty three families were identified in all the transects (Table 2).

The dominant plant families recorded in the area are: Leguminosae, Rubiaceae, Euphorbiaceae, Apocynaceae, Sterculiaceae with the following percentages 12.63\%, 8.42\%, 7.89\%, 5.26\% and $3.68 \%$ respectively. Sapindaceae and Moraceae have the same percentage of $3.16 \%$. However, other families accounted for between $0.53 \%$ to $2.11 \%$ (Table 2 ).

Among the sixty-three families, climbers have the highest family of 26 , followed by tree 24 , shrub 23 and herb 20. Also, of the entire plant form tree has the highest number of species 67 , climber 50 , shrub 45 , and herb 28 respectively. In terms of the relative abundance of the plant form, tree and shrub are the most abundant 1060 (31.74\%) and 1057 (31.63\%) while climber and herb have $833(24.94 \%)$ and 390 (11.68\%) abundant respectively (Table 3).

Ten plant species are the most abundant species in all transects. These are Culcasia saxatilis (4.46\%), Icacina trichantha (4.10\%), Alchornea laxiflora (3.86\%), Sphenocentrum jollyanum (3.50\%), Chassalia kolly (3.38\%), Microdesmis puberula (3.23\%), Newbouldia laevis (3.23\%), Deinbolla pinnata (2.69\%), Funtumia elastica (2.63\%) and Combretum zenkeri (2.28\%) respectively (Table 4).

\section{Simpson Diversity and Similarity Indices of Plant Species}

Table 5 shows the species' richness (diversity of plant in the transects). Transect $D$ has the highest plant diversity index of 0.01184 , transect $A$ and $B$ have a high diversity indices of 0.01638 and 0.01675 respectively, while transect $C$ has the least diversity index of 0.02091 respectively. It could therefore be deducted that transect $D$ is richer in plant species than all other transects, followed by transect $A, B$, and lastly transect $C$. When data from all transects were added together, the result showed a much higher plant diversity of 0.00322 in the forest.

In table 6, the Simpson similarities indices of transects varied from $50.75 \%$ to $42.76 \%$ for transects $B$ and $C, A$ and $C$, and $C$ and $D$ respectively. Transect $B$ and $C$ have a high similarities index of $50.75 \%$ followed by transect $A$ and $B$ with $45.45 \%$. Transect $B$ and $D$, and $A$ and $D$ has a moderate value of $43.36 \%$, and 43.14\% respectively. Transect $A$ and $C$, and $C$ and $D$ had the same but low similarities index of $42.76 \%$ when compared with other transects. Transect $B$ and $C$, which have the highest percentage of similarities index (50.75\%) are similar to each other in terms of plant species between the two transects. The result 
Ariyo, Oluwalana, Faleyimu \& Ariyo

generally showed that the similarity indices of plant between transect apart from transects $B$ and $C$ is low, less than $50 \%$.

\section{DISCUSSION}

The result of the study showed a high diversity of plant species (190 species) from 63 families despite the disturbance that had occurred in the area such as hunting, land clearing for experiment, construction of physical structure, firewood, poles and stakes collection and occasional but illegal felling of timber. Poaching of bats in the forest reserve is also associated with cutting down of young trees. Isichei (1996) observed that succession restores and increase diversity of life in an area after disturbance. Also according to Ayodele and Lameed (1999), species' diversity is well correlated with the annual amount of rainfall with the water areas tending to be rich in species diversity in the southern parts of Nigeria. The abundance of plant species in the forest reserved may be due to the combined effects of favourable climatic conditions and protection over many years which enhance regeneration.

The most abundant plant species in the forest are mostly secondary colonizers climbers, shrubs and trees such as Culcasia saxatilis, Icacina trichantha, Shrub: Alchornea laxiflora, Sphenocentrum jollyanum, Chassalia kolly, Microdesmis puberula, Deinbolla pinnata, followed by tree: Newbouldia laevis, and Funtumia elastica respectively. All these with other plants grow in association with each other to form large thickets in the forest. This is supported by Bourgeron, 1983 and Brunig, 1983 that thickets commonly occur in tropical forests in response to disturbance. Their pervasiveness and persistence are noted by GriegSmith (1952), that the secondary forest occurring even 30 years after cultivation resulted in a tangle of vegetation much less regularly layered in structure than non-cultivated secondary forest. It has been suggested that thickets are an aggregation of individuals which, while they may have competed with each other in the past, essentially coexist without detriment to one another and may even proffer some protective advantages to constituent individuals (Grieg-Smith, 1952; Brunig, 1983).

In terms of plant diversity, transect $D$ showed the highest plant diversity index of 0.01184 , followed by transects $A$ and $B(0.01638$ and 0.01675$)$ while transect $C$ showed a relatively low diversity indices of 0.02091 respectively. In terms of intra species (alpha diversity), transect $D$ also has the highest diversity (111 species), followed by transect $\mathrm{A}$ (109 species), transect C (106 species) and transect $B$ (97 species). In term of Gamma diversity (individual species), transect D recorded the highest diversity of 1016 plants followed by transect $A(848)$ while transect $B$ and $C$ recorded 746 and 730 plants respectively. It follows that transect $D$ is richer in plant species and individual species (alpha and gamma) than all other transects. When data from all transects were added together; the result shows a much higher alpha and gamma diversity of (190 and 3340) and Simpson diversity index of 0.00322 . The Simpson diversity index is however low when compared with the value of over 0.90 obtained for the species-rich evergreen forests of the Western Ghats (Pascal, 1988). 
Beta diversity which compares the similarity between transects as suggested by Wolda (1983) shows that transect $B$ and $C$ are highly similar with the value of $50.75 \%$, this is followed by transect $A$ and $B$ 45.45\%. Transect $A$ and $D$ and $B$ and $D$ are similar with each other with $43.14 \%$ and $43.36 \%$ while transect $A$ and $C$ and $C$ and $D$ are equally similar, but having the lowest similarities' indices of $42.76 \%$. Transect $B$ and $C$, which have the highest percentage of similarities indices (50.75\%) are similar to each other in terms of plant species and composition between the two transects. Transect $B$ and $C$ have 68 plant species in common, transect $B$ has 28 plant species that were not found in transect $C$ while transect $C$ has 38 plant species that were not found in transect $B$. The result generally shows that the similarities indices of plant between transect apart from transect B and C were low, less than $50 \%$.

\section{CONCLUSION}

The study shows high diversity of plants from sixty three families. The dominant plant families are Leguminosae, Rubiaceae, Euphorbiaceae, Apocynaceae and Sterculiaceae. The reserve is also reasonably well- stocked with multiplicity of species with tree having the highest number of species followed by shrubs, climber and herbs respectively. Though open areas with large gaps without trees were noticed in the reserve. Thus, the forest reserve of IITA is more diverse in plant species and serves as reservoir of plants that could be useful as timber and non timber forest products. Adequate protection of the site should be a priority to prevent loss of diversity of plants from the Reserve.

\section{RECOMMENDATIONS}

Based on the outcome of the study, the following recommendations were made.

1. Adequate protection and conservation of the forest reserve to prevent illegal felling of trees and removal of poles, firewood, stakes or any other forest products that may lead to loss of plants diversity should be given priority.

2. Enrichment planting of trees should be carried out in open areas or areas with large gaps to enhance the development of the forest reserve towards a mature succession stage. This should be done systematically by first locating and mapping out such areas.

3. Environmental education and enlightenment of IITA staff and villagers living around the perimeter fence on the need to conserve and protect the forest. This will reduce illegal felling of trees and poaching;

4. Development of buffer zone as presently obtained in IITA where villagers would be allowed to collect firewood, palm products, vegetables, medicinal plants and other forest products for their immediate needs. However, they should be restricted to such reserve and not allow encroaching into protected areas. 
Ariyo, Oluwalana, Faleyimu \& Ariyo

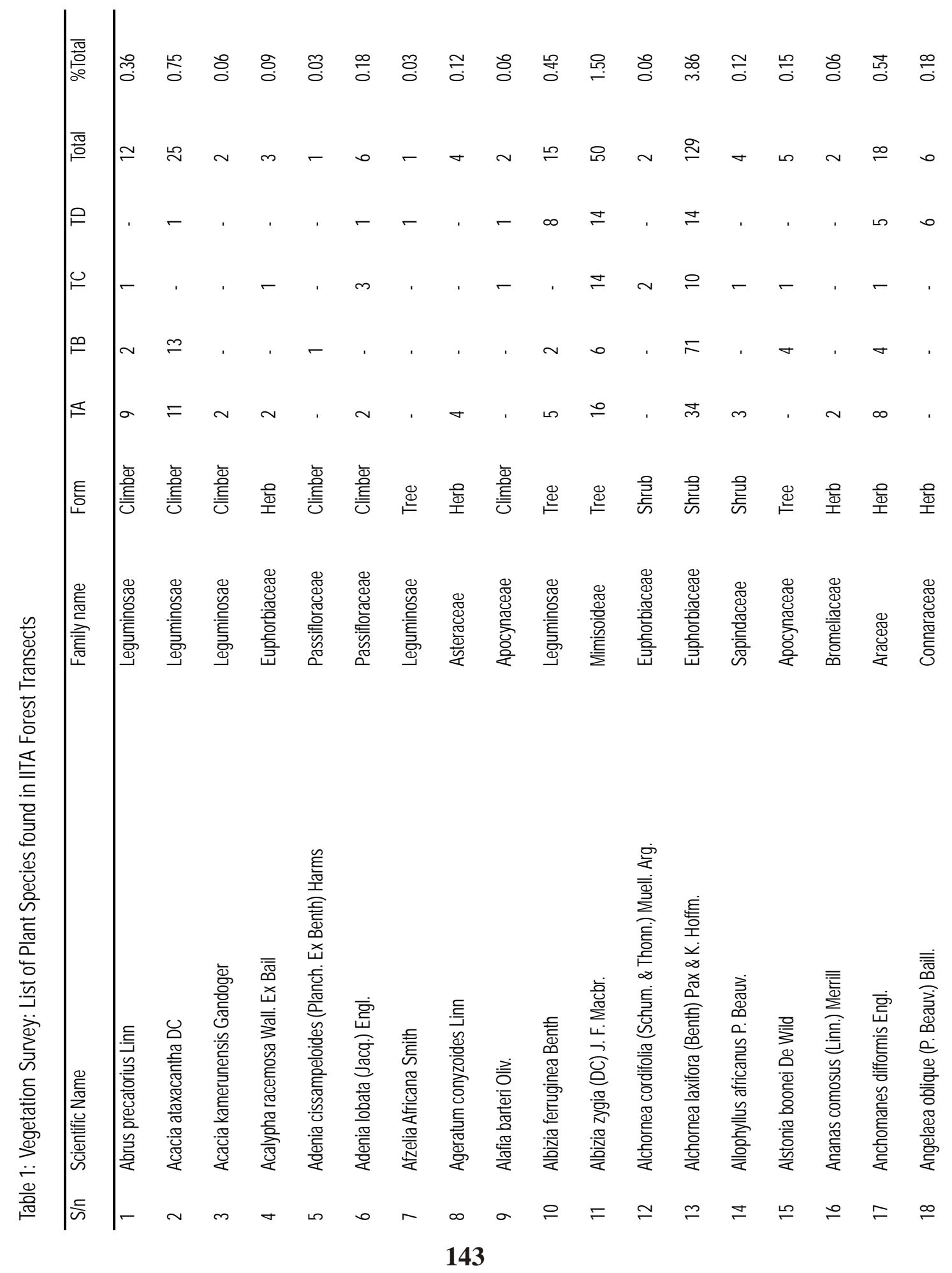


Ariyo, Oluwalana, Faleyimu \& Ariyo

$$
\begin{aligned}
& \text { సี }
\end{aligned}
$$

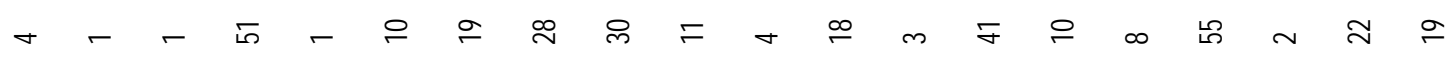

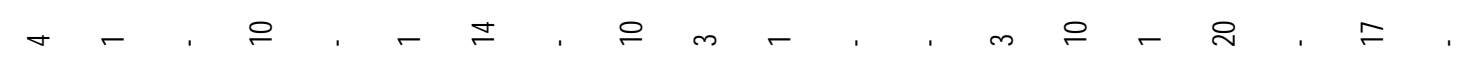

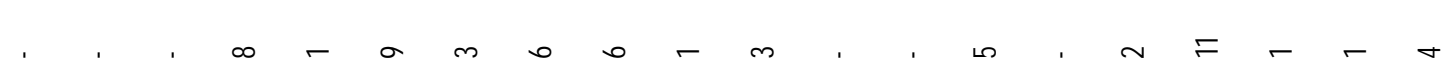

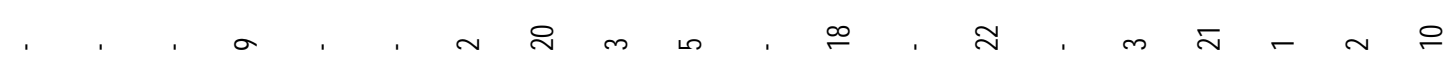

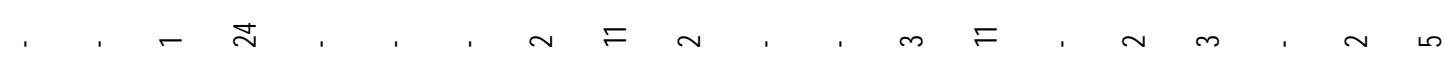

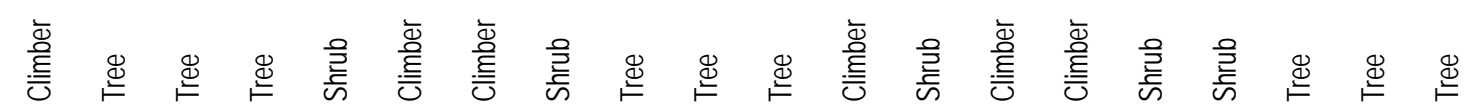
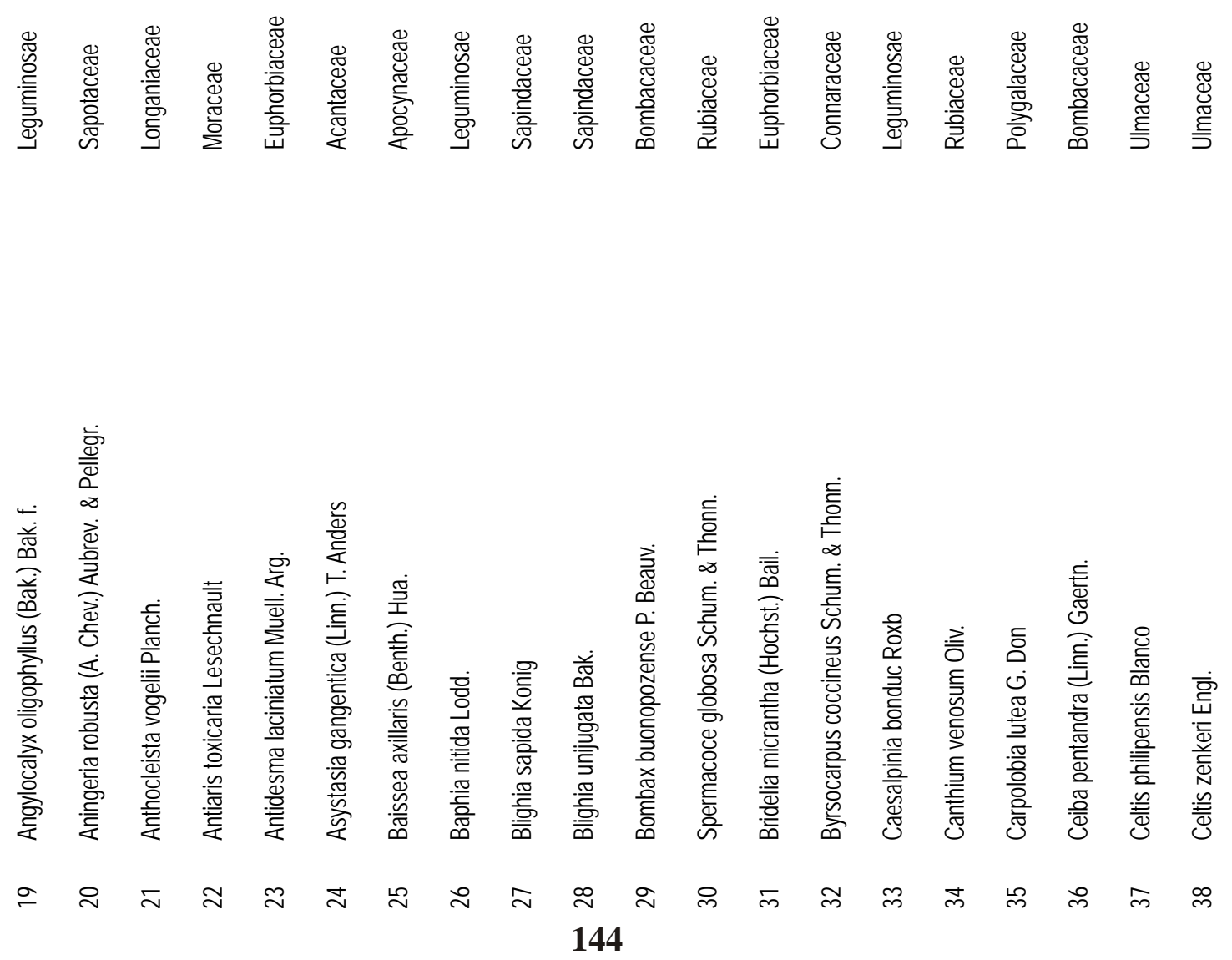
Ariyo, Oluwalana, Faleyimu \& Ariyo

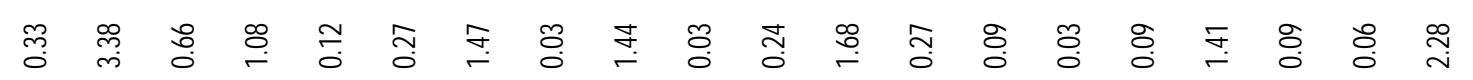

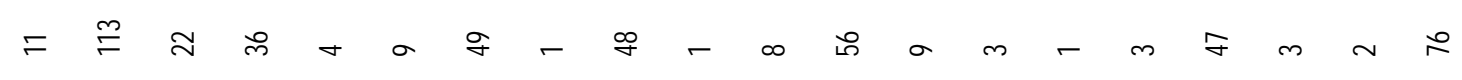

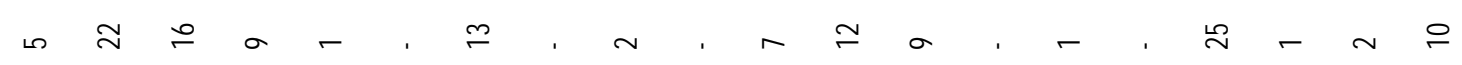

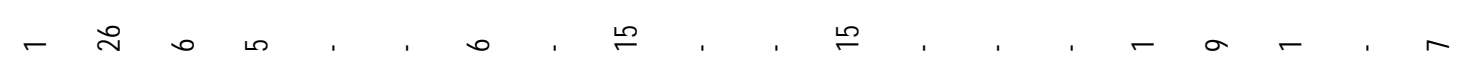

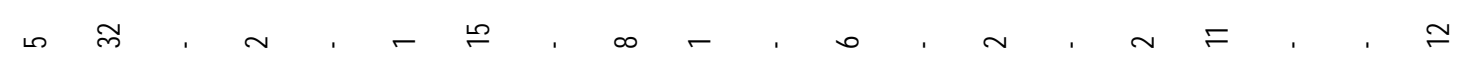

,

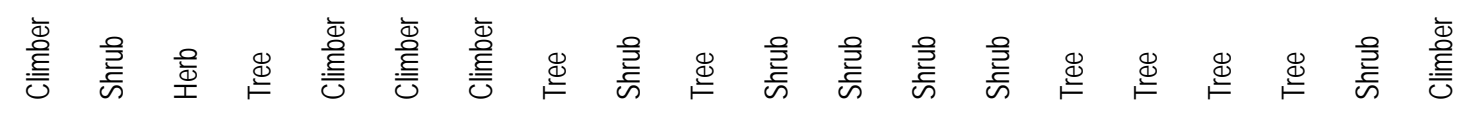

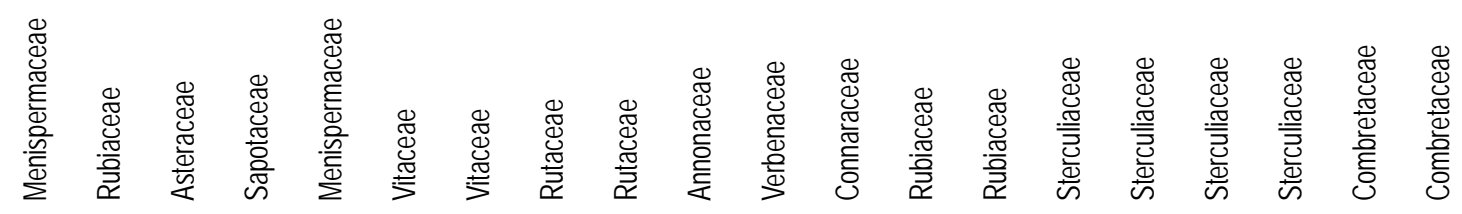

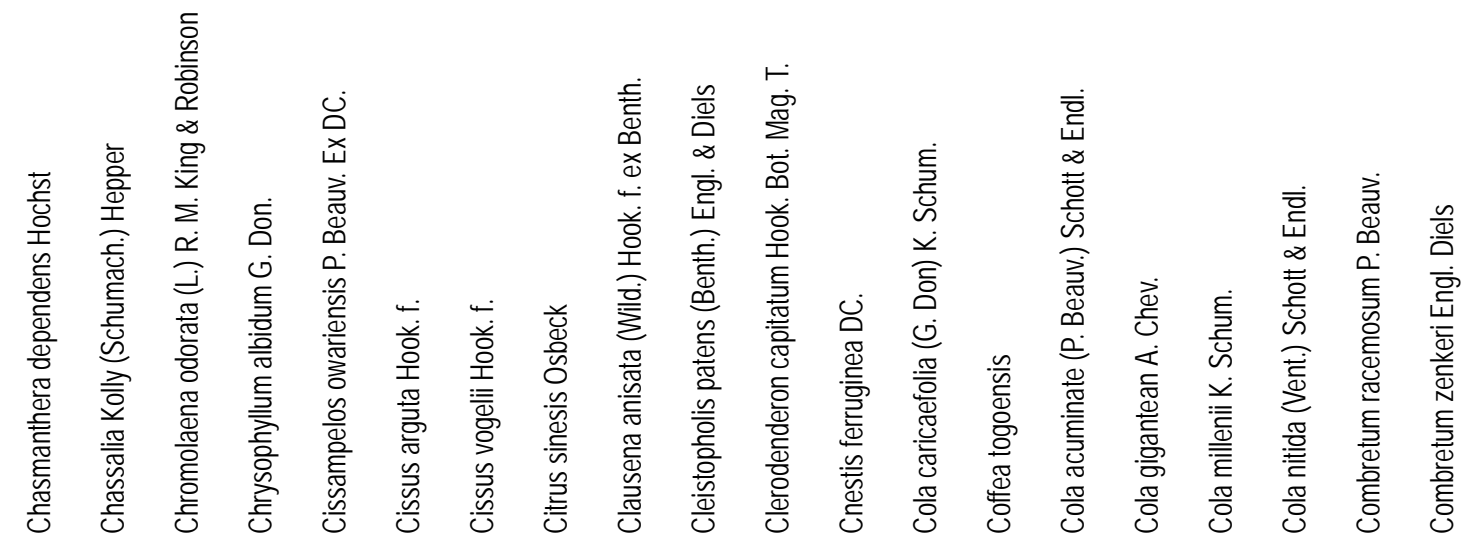

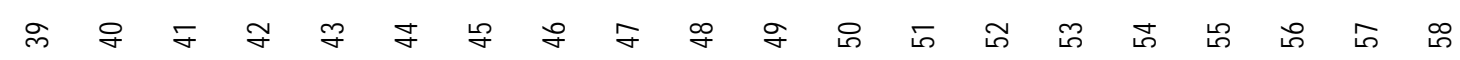


Ariyo, Oluwalana, Faleyimu \& Ariyo

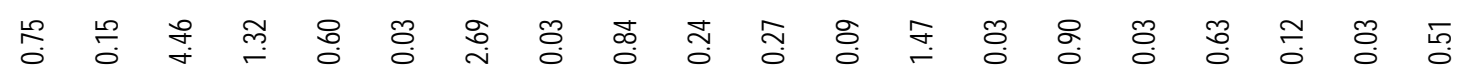

ก

m

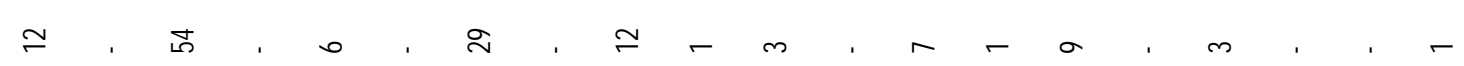

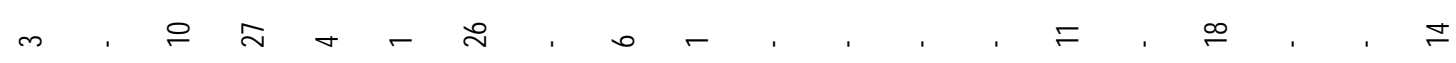

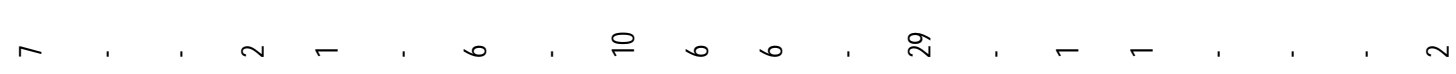

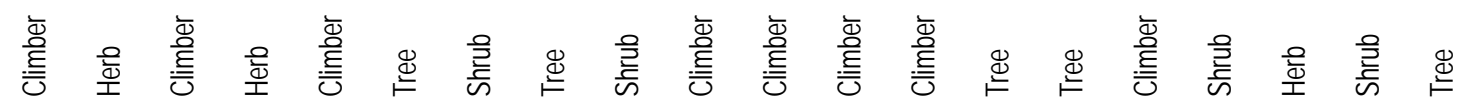

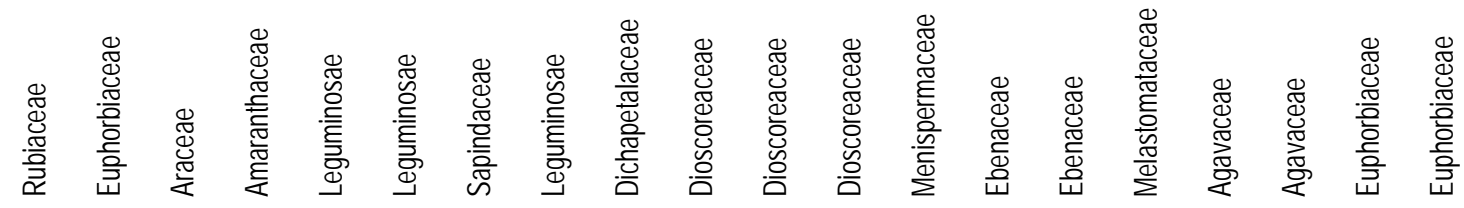

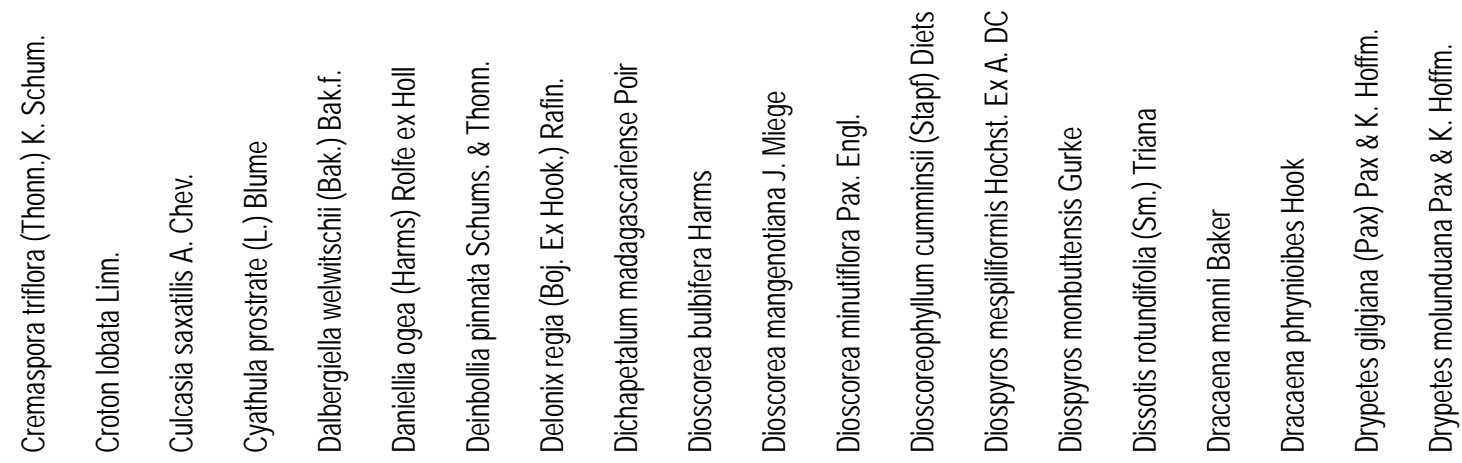

品 8 எ 
Ariyo, Oluwalana, Faleyimu \& Ariyo

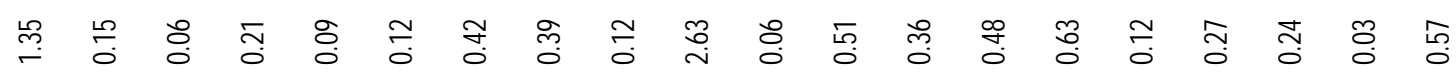

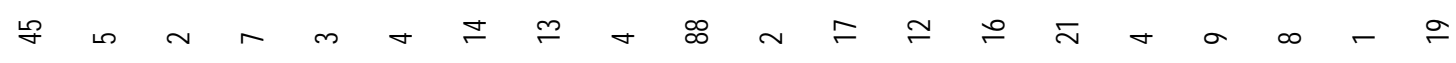

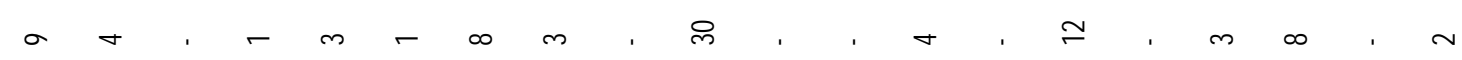

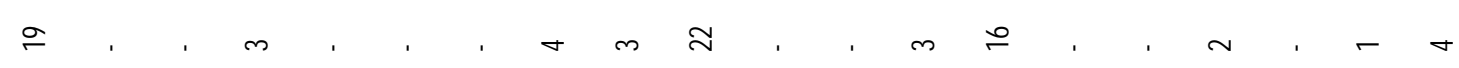

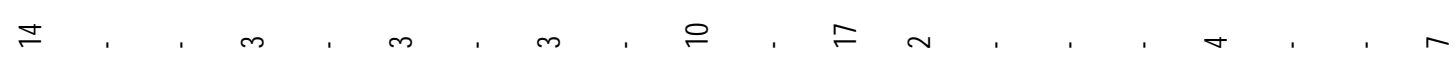

$m-\infty, 1,0,0,0,0,0,1,0$

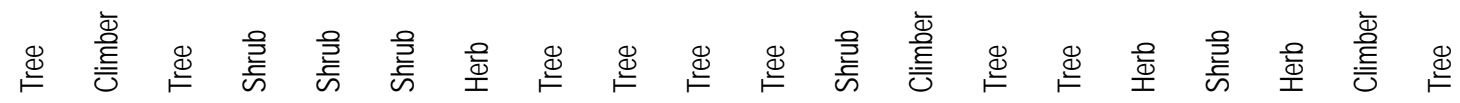

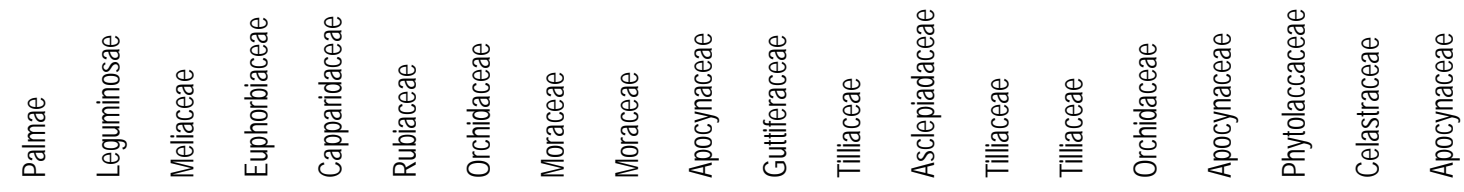

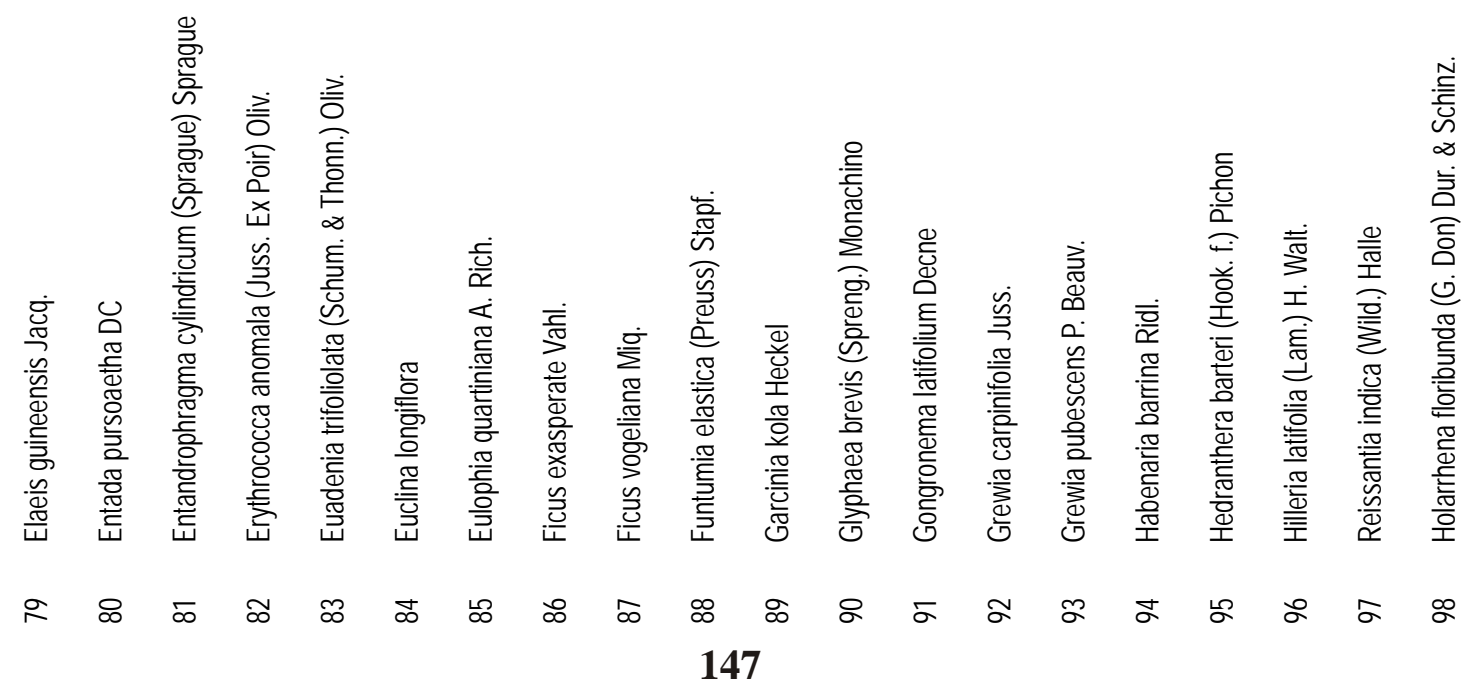


Ariyo, Oluwalana, Faleyimu \& Ariyo

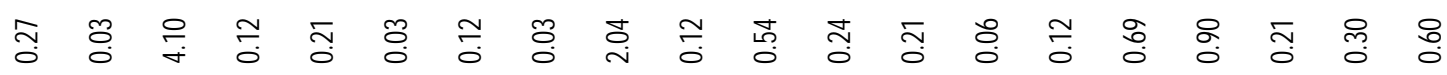

๑)

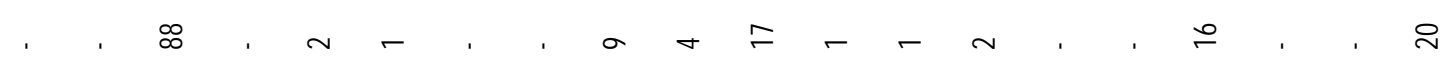

, $9, .,+2$

$0 \rightarrow \wedge,$, ,

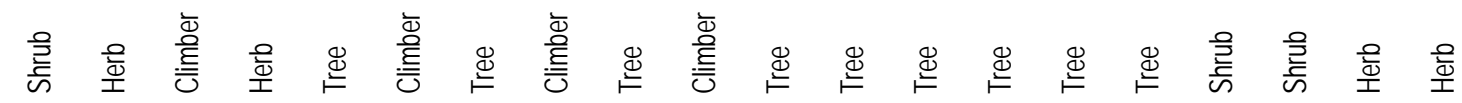
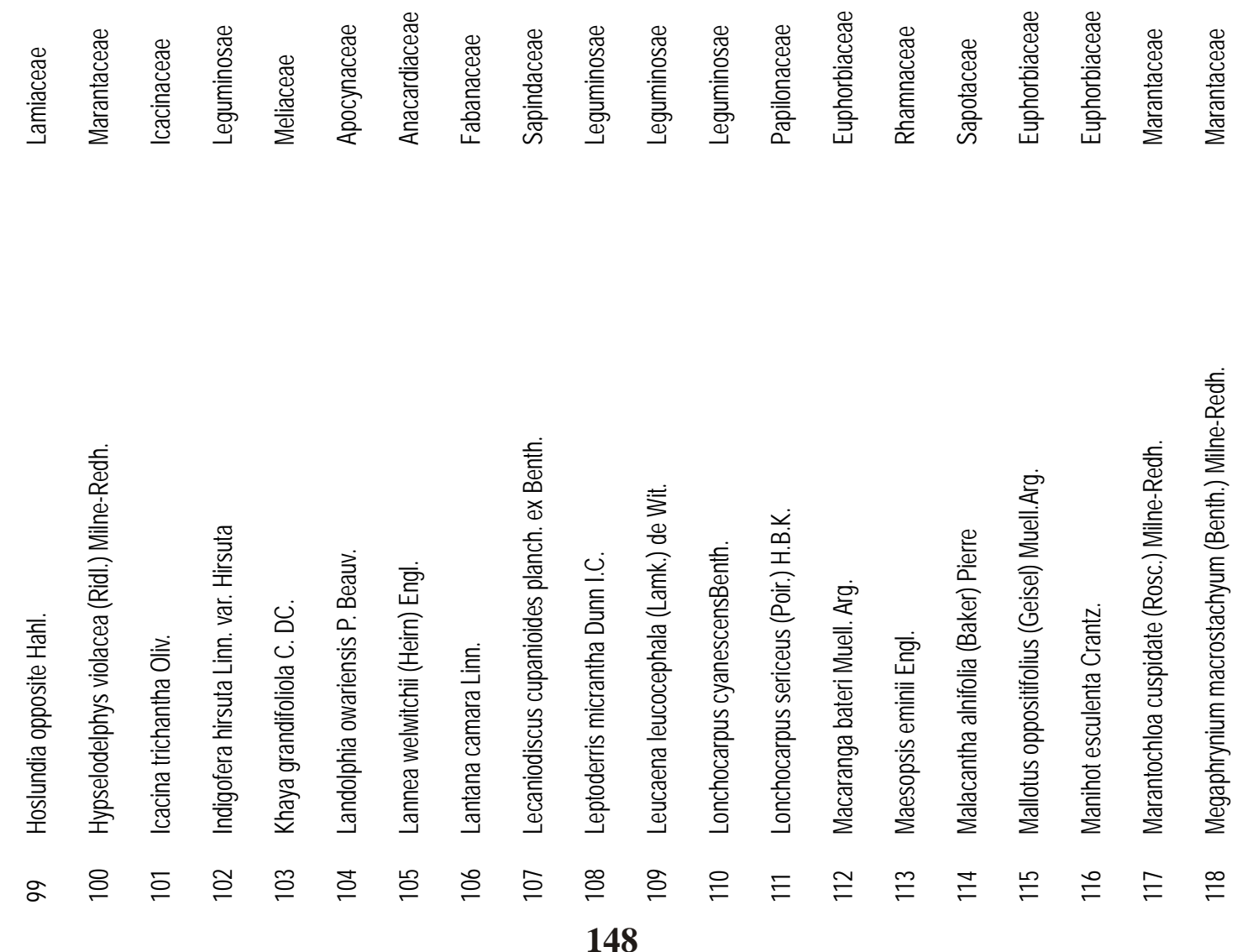
Ariyo, Oluwalana, Faleyimu \& Ariyo

$$
\begin{aligned}
& \text { ஜ }
\end{aligned}
$$

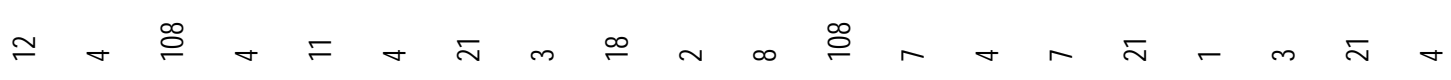

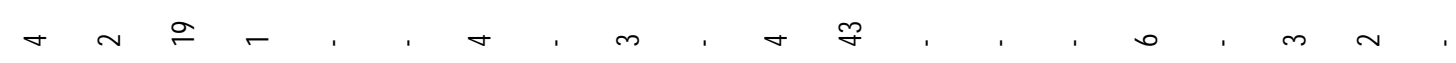

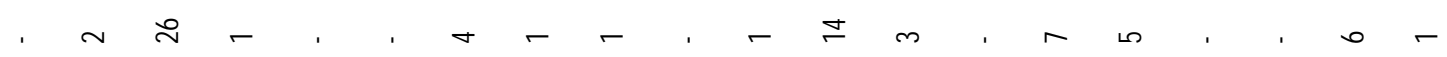
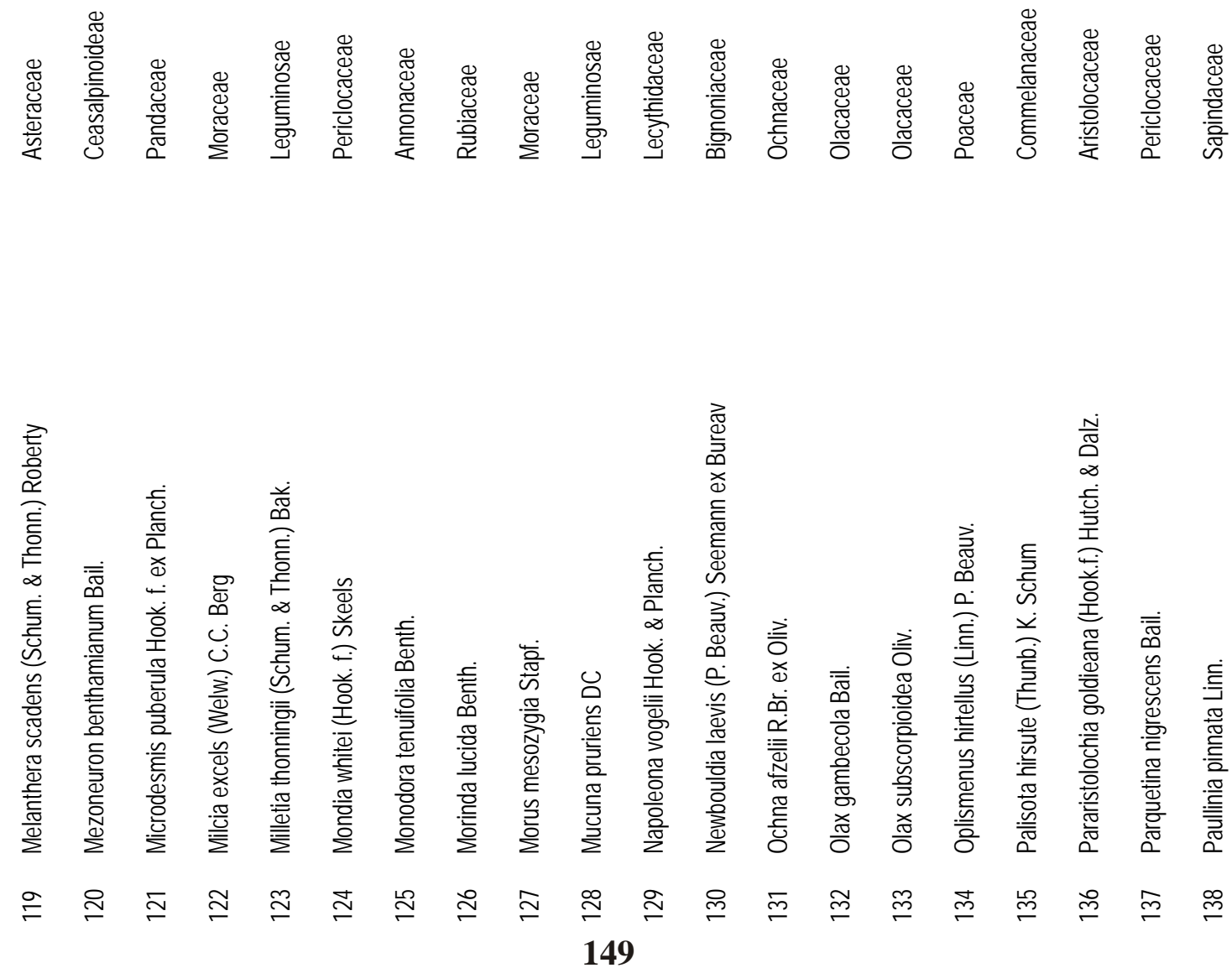
Ariyo, Oluwalana, Faleyimu \& Ariyo

ন্் 宁

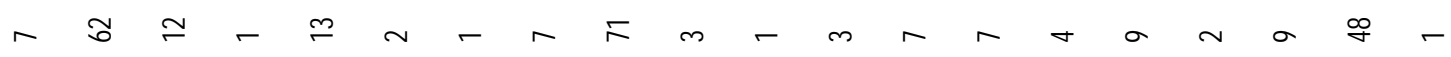

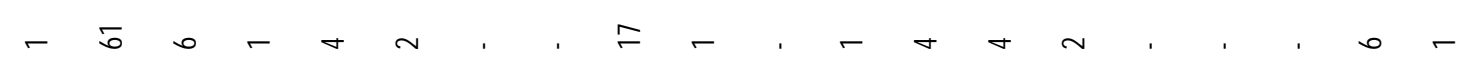

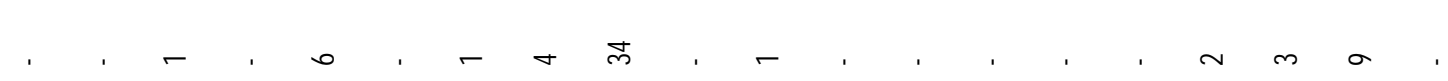

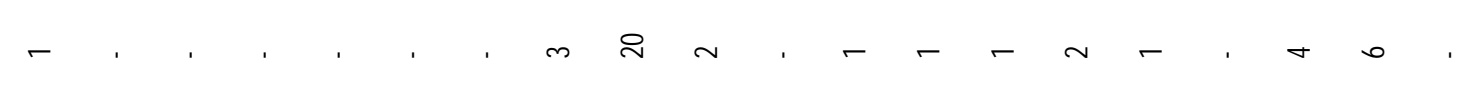

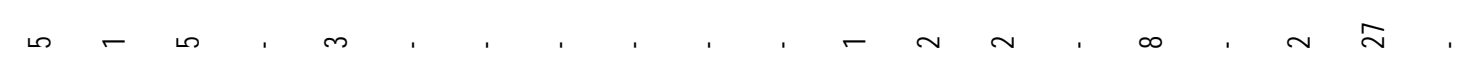

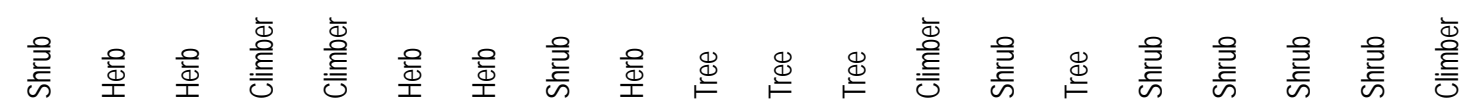

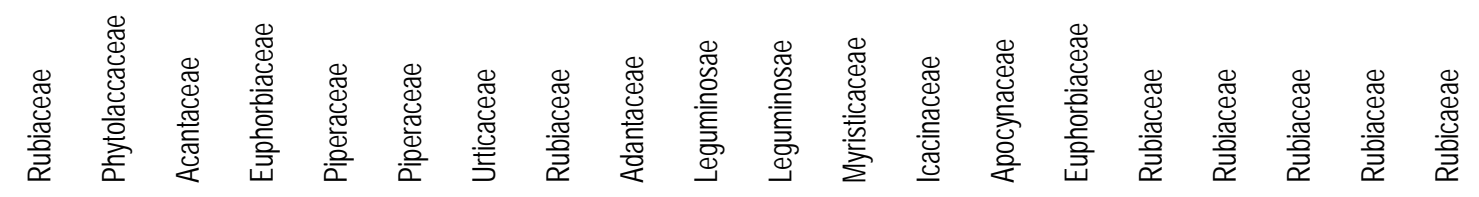

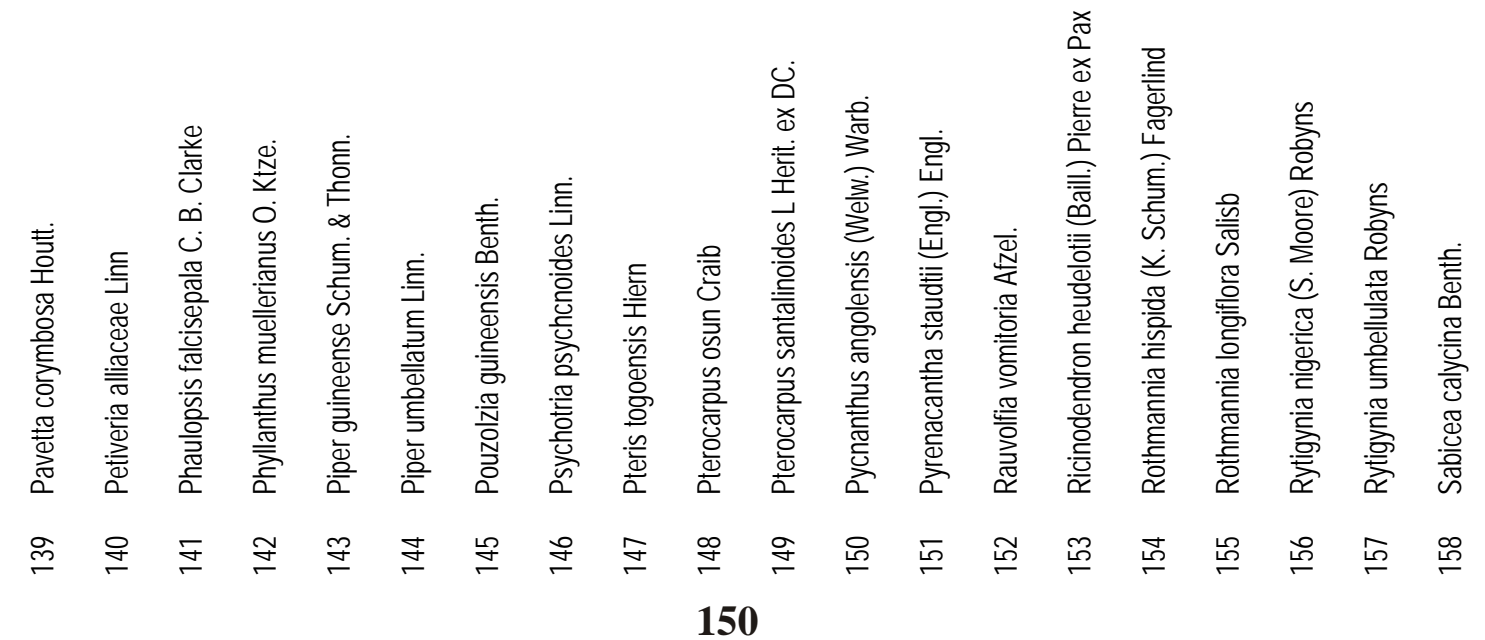


Ariyo, Oluwalana, Faleyimu \& Ariyo

‡゙ స్ํ

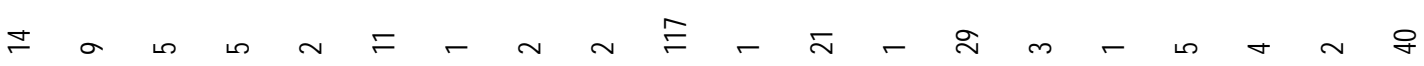

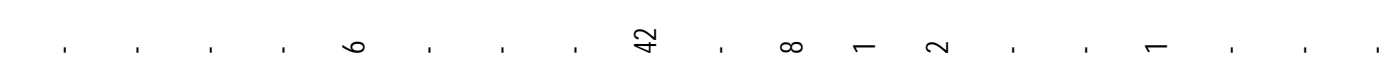

$\sim \diamond+, \rightarrow, \infty, \infty, \infty, \infty, \infty, \infty$

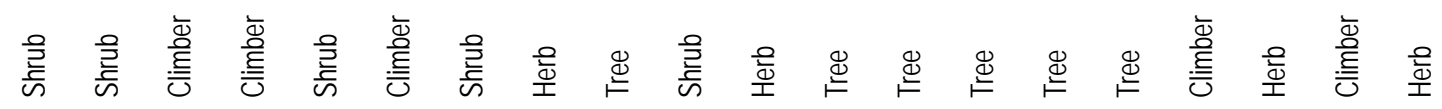
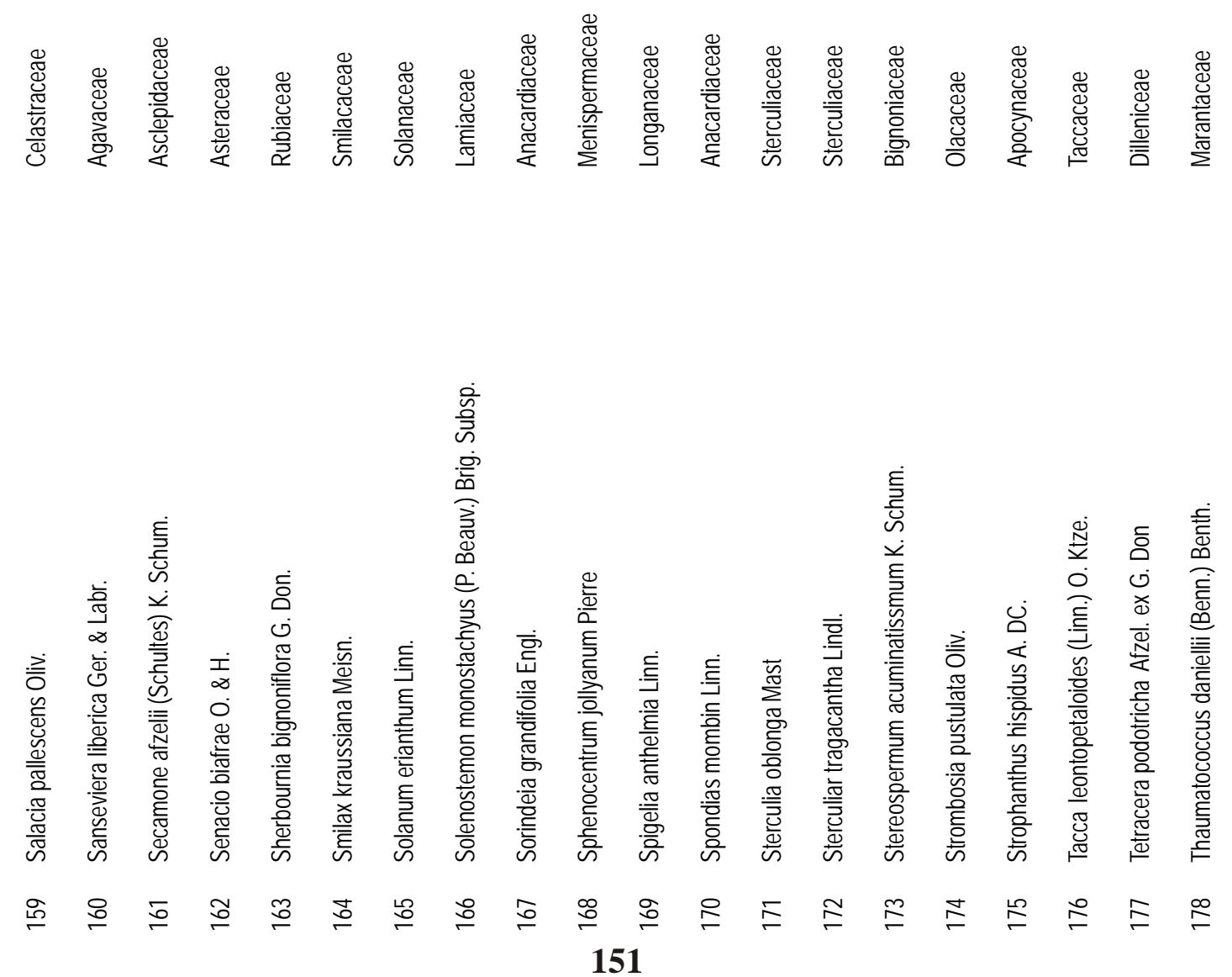
Ariyo, Oluwalana, Faleyimu \& Ariyo

$$
\begin{aligned}
& \text { 융 ్ㅜ }
\end{aligned}
$$

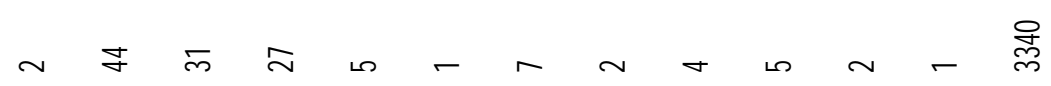

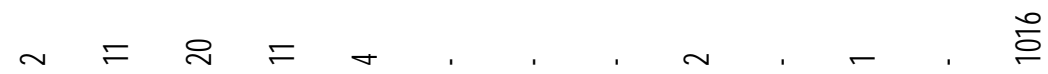

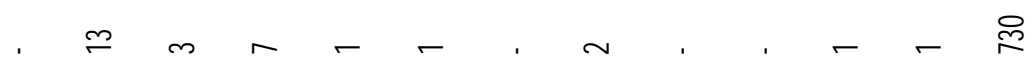

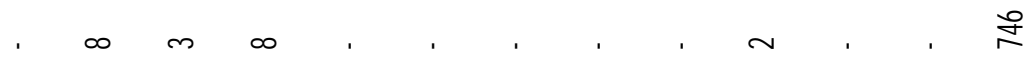

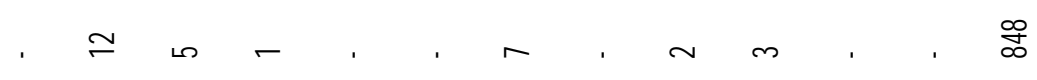

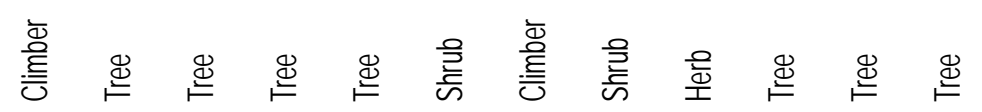

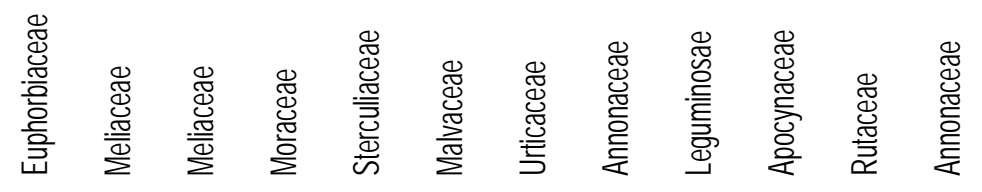

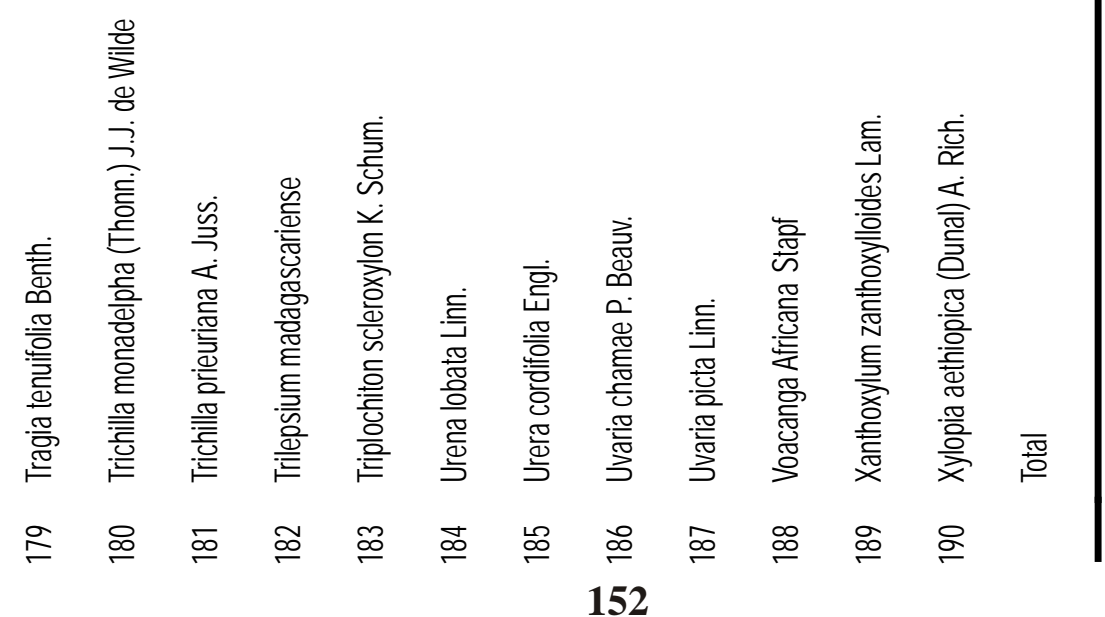


Ariyo, Oluwalana, Faleyimu \& Ariyo

Table 2: Vegetation Survey: List of Plant Families, Frequency and their Percentages in all the Forest Transects

\begin{tabular}{|c|c|c|c|}
\hline s/n & Family Name & Frequency & Percentage \\
\hline 1 & Acantaceae & 2 & 1.05 \\
\hline 2 & Adantaceae & 1 & 0.53 \\
\hline 3 & Agavaceae & 3 & 1.58 \\
\hline 4 & Amaranthaceae & 1 & 0.53 \\
\hline 5 & Anacardiaceae & 3 & 1.58 \\
\hline 6 & Annonaceae & 4 & 2.11 \\
\hline 7 & Apocynaceae & 10 & 5.26 \\
\hline 8 & Araceae & 2 & 1.05 \\
\hline 9 & Aristolocaceae & 1 & 0.53 \\
\hline 10 & Asclepiadaceae & 2 & 1.05 \\
\hline 11 & Asteraceae & 4 & 2.11 \\
\hline 12 & Bignoniaceae & 2 & 1.05 \\
\hline 13 & Bombacaceae & 2 & 1.05 \\
\hline 14 & Bromeliaceae & 1 & 0.53 \\
\hline 15 & Capparidaceae & 1 & 0.53 \\
\hline 16 & Celastraceae & 2 & 1.05 \\
\hline 17 & Combretaceae & 2 & 1.05 \\
\hline 18 & Commelanaceae & 1 & 0.53 \\
\hline 19 & Connaraceae & 3 & 1.58 \\
\hline 20 & Delleniceae & 1 & 0.53 \\
\hline 21 & Dichapetalaceae & 1 & 0.53 \\
\hline 22 & Dioscoreaceae & 3 & 1.58 \\
\hline 23 & Ebenaceae & 2 & 1.05 \\
\hline
\end{tabular}


Ariyo, Oluwalana, Faleyimu \& Ariyo

\begin{tabular}{|c|c|c|c|}
\hline 24 & Euphorbiaceae & 15 & 7.89 \\
\hline 25 & Fabanaceae & 1 & 0.53 \\
\hline 26 & Guttiferaceae & 1 & 0.53 \\
\hline 27 & Icacinaceae & 2 & 1.05 \\
\hline 28 & Lamiaceae & 2 & 1.05 \\
\hline 29 & Lecythidaceae & 1 & 0.53 \\
\hline 30 & Leguminosae & 24 & 12.63 \\
\hline 31 & Longaniaceae & 2 & 1.05 \\
\hline 32 & Malvaceae & 1 & 0.53 \\
\hline 33 & Maranthaceae & 4 & 2.11 \\
\hline 34 & Melastomataceae & 1 & 0.53 \\
\hline 35 & Meliaceae & 4 & 2.11 \\
\hline 36 & Menispermaceae & 4 & 2.11 \\
\hline 37 & Moraceae & 6 & 3.16 \\
\hline 38 & Myristicaceae & 1 & 0.53 \\
\hline 39 & Ochnaceae & 1 & 0.53 \\
\hline 40 & Olacaceae & 3 & 1.58 \\
\hline 41 & Orchidaceae & 2 & 1.05 \\
\hline 42 & Palmae & 1 & 0.53 \\
\hline 43 & Pandaceae & 1 & 0.53 \\
\hline 44 & Passifloraceae & 2 & 1.05 \\
\hline 45 & Periclocaceae & 2 & 1.05 \\
\hline 46 & Phytolaccaceae & 2 & 1.05 \\
\hline 47 & Piperaceae & 2 & 1.05 \\
\hline 48 & Poaceae & 1 & 0.53 \\
\hline 49 & Polygalaceae & 1 & 0.53 \\
\hline
\end{tabular}




\begin{tabular}{llll}
50 & Rhamnaceae & 1 & 0.53 \\
51 & Rubiaceae & 16 & 8.42 \\
52 & Rutaceae & 3 & 1.58 \\
53 & Sapindaceae & 6 & 3.16 \\
54 & Sapotaceae & 3 & 1.58 \\
55 & Smilacaceae & 1 & 0.53 \\
56 & Solanaceae & 1 & 0.53 \\
57 & Sterculiaceae & 7 & 3.68 \\
58 & Taccaceae & 1 & 0.53 \\
59 & Tilliaceae & 3 & 1.58 \\
60 & Ulmaceae & 2 & 1.05 \\
61 & Urticaceae & 2 & 1.05 \\
62 & Verbenaceae & 1 & 0.53 \\
63 & Vitaceae & 2 & 1.05 \\
\hline
\end{tabular}

Table 3: Vegetation Survey: Total Number, Frequency, Percentages and Family of Climber, herb, shrub and tree found in all the forest transects

\begin{tabular}{lllllll}
\hline $\begin{array}{l}\text { Plant } \\
\text { Form }\end{array}$ & $\begin{array}{l}\text { Species } \\
\text { no/0.4ha }\end{array}$ & $\begin{array}{l}\text { Percentage } \\
\text { Species }\end{array}$ & $\begin{array}{l}\text { Species } \\
\text { Frequency }\end{array}$ & $\begin{array}{l}\text { Percentage of } \\
\text { Total Freq. }\end{array}$ & $\begin{array}{l}\text { Plant } \\
\text { Family }\end{array}$ & $\begin{array}{l}\text { Percentage of } \\
\text { Plant Family }\end{array}$ \\
\hline Climber & 50 & 26.32 & 833 & 24.94 & 26 & 27.96 \\
Herb & 28 & 14.74 & 390 & 11.68 & 20 & 21.51 \\
Shrub & 45 & 23.68 & 1057 & 31.65 & 23 & 24.73 \\
Tree & 67 & 35.26 & 1060 & 31.74 & 24 & 25.81 \\
Total & 190 & & 3340 & & 93 & \\
\hline
\end{tabular}


Ariyo, Oluwalana, Faleyimu \& Ariyo

Table 4: Most Abundant Plant Species in all the Transects

\begin{tabular}{llllcc}
\hline S/n & Plant species & Family & Form & Frequency $\begin{array}{c}\text { Percentage } \\
\text { of Total } \\
\text { Species }\end{array}$ \\
\hline 1 & Culcasia saxatilis & Araceae & Climber & 149 & 4.46 \\
2 & Icacina trichantha & Icacinaceae & Climber & 137 & 4.10 \\
3 & Alchornea laxiflora & Euphorbiaceae & Shrub & 129 & 3.86 \\
4 & Sphenocentrum jollyanum & Menispermaceae & Shrub & 117 & 3.50 \\
5 & Chassalia kolly & Rubiaceae & Shrub & 113 & 3.38 \\
6 & Microdesmis puberula & Pandaceae & Shrub & 108 & 3.23 \\
7 & Newbouldia laevis & Bignoniaceae & Tree & 108 & 3.23 \\
8 & Deinbolla pinnata & Sapindaceae & Shrub & 90 & 2.69 \\
9 & Funtumia elastica & Apocynaceae & Tree & 88 & 2.63 \\
10 & Combretum zenkeri & Combretaceae & Climber & 76 & 2.28 \\
\hline
\end{tabular}

Table 5: Simpson Diversity Index of plant species in the forest

\begin{tabular}{ccccc}
\hline Transect & $\mathrm{n}$ & $\mathrm{N}$ & Diversity & Inversed diversity \\
\hline A & 109 & 848 & 0.01638 & 61.01 \\
B & 97 & 746 & 0.01675 & 59.70 \\
C & 106 & 730 & 0.02091 & 47.82 \\
D & 111 & 1016 & 0.01184 & 84.46 \\
All transect & 190 & 3340 & 0.00322 & 310.56 \\
\hline
\end{tabular}

Table 6: Simpson Similarities Index of plant species in the forest

\begin{tabular}{ccccc}
\hline Transect & A & B & C & D \\
\hline A & $*$ & $45.45 \%$ & $42.76 \%$ & $43.14 \%$ \\
B & $*$ & $50.75 \%$ & $43.36 \%$ \\
C & & $*$ & $42.76 \%$ \\
D & & & $*$ \\
\hline
\end{tabular}




\section{REFERENCES}

Ardakani, M. R. (2004). Ecology. Tehran University Press, 340pp.

Ayodele, I.A. and Lameed, G.A. (1999). Essentials of Biodiversity. Power house press and publishers Ibadan. 1-17.

Badejo, M.A. (1996). Measuring the diversity of soil micro flora and macro flora in an area of conservation biodiversity. In: Assessment and Monitoring technique in Nigeria (ed (s) B.A. Ola-Adams and L.O. Ojo. National Committee of Man and Bushphere pg. 89.

Begossi, A. (1996). Use of ecological methods in ethnobotany: diversity indices. Economic Botany 50 : 280-289.

Bourgeron, P.S. (1983). Spatial aspects of vegetation structure. Tropical rain Forest Ecosystems: Structure and Function Ecosystems of the World. Elsevier Scientific Publishing Co., New York. 14: $29-47$

Brunig, E.F. (1983). Vegetation structure and growth. Tropical Rain Forest Ecosystems: Structure and Function Ecosystems of the World Elsevier Scientific Publishing Co., New York. 14: 49-75.

Ezealor, A.U.ed. (2002). Critical sites for biodiversity conservation in Nigeria. Nigeria Conservation Foundation: Lagos, Nigeria.

Figueiredo, G.M., Leitao-Filho, H.F., and Begossi, A. (1993). Ethnobotany of Atlantic forest coastal communities diversity of uses in Gamboa (Itacuruca Island, Brazil). Human Ecology 21: 419-430.

Figueiredo, G.M., Leitao-Filho, H.F., and Begossi, A. (1997). Ethnobotany of Atlantic forest communities. II. Diversity of plants uses at Sepetiba Bay (SE-Brazil). Human Ecology 25: 353-360.

Fox, R., Rowntree, K. (2000). The Geography of South Africa in a Changing World. Oxford University.

Gauch, H.E. (1986). Multivariate in community ecology. Cambridge University Press 298pp.

Grieg-Smith, P. (1952). Ecological observations on degraded and secondary forest in Trinidad, British West Indies. II. Structure of the communities. Journal of Ecology, 40:, 316-330.

Groombridge, B., Jenkins, MD (2002). World Atlas of Biodiversity: Earth's living resources in the 21st century. University of California Press, Berkeley.

Groves, CR (2002). Drafting a conservation blueprint: A practitioner's guide to planning for biodiversity. Island Press, Washington.

Isichei, A.O. (1996). Biodiversity conservation and sustainable development: Ecology Assessment and Monitoring of Biodiversity in Nigeria. In: Assessment and Monitoring technique in Nigeria (ed (s) B.A. Ola-Adams and L.O. Ojo. National Committee of Man and Bushphere. Pp 107-115.

Jost, L., (2006). Entropy and diversity. Oikos, 113:363-375.

Kokwaro, J.O. (1994). An Overview of Current Status of Biodiversity in Africa. Whydah News/etter Africa Academy of Science 3(9):1-8.

Koleff, P., Gaston, K., Lennon, J., (2003). Measuring beta diversity for presence/absence data. J. Anim. Ecol., 72: 367-382.

Koop, H., (1989). Forest Dynamics. Silvi-star:A Comprehensive Monitoring System. Springer, Berlin.

Lennon, J., Koleff, P., Greenwood, J.J., Gaston, K., (2001). The geographical structure of British bird distributions: diversity, spatial turnover and scale. J. Anim. Ecol., 70: 966-979.

Lindgren, P.M.F., Sullivan, T.P., (2001). Influence of alternative vegetation management treatments on conifer plantation attributes: abundance, species diversity and structural diversity. For. Ecol. Manage. 142:, 163 - 182. 
Magurran, AE (2004). Measuring biological diversity. Blackwell Publishing; Oxford, United Kingdom.: 256.

Mogaka, H., (2002). Economic instruments for the reduction of forest biodiversity loss in Kenya. GEF/UNDP/FAO Cross Border Biodiversity Project- Reducing Biodiversity Loss at selected. Cross-Border Sites in East Africa. Economics Component Technical Report, No. 16:, 43. Nairobi.

Ojo, L.O. (1993). Estimation of carbon dioxide uptake and emission from deforestation of the Nigerian forests. Nigerian Journal of Forestry. 23: 33-41.

Ojo, L.O. (1996). Data Collection and Analysis for Biodiversity Conservation: In: Assessment and Monitoring technique in Nigeria (ed (s) B.A. Ola-Adams and L.O. Ojo. National Committee of Man and Bushphere. 142-145.

Pascal, JP. (1988). Wet ever green forests of the Western Ghats of India. French Institute, Pondicherry, India: 343.

Phillips O.L. (1996). Long term environmental changes in tropical forests: increasing tree Turnover. Environmental Conservation 23: 235-248.

Saye, J.A. and Wegge, P. (1992). Biological Conservation issues in Forest Management. The IUCN Forest Conservation, Programme. Proceedings of Workshop held at the IUCN General Assembly Perth Australia, $30^{\text {th }}$ Nov. $-1^{\text {st }}$ Dec., 1990. Ed (s) J.U.M. Block House, M.A. Dillenbe, J.A. Sayer and P. Wegge. 1-244.

Simpson, E.H. (1949). "Measurement of diversity," Nature, 163-188.

Sorensen, T. (1948). "A method of establishing groups of equal amplitude in plant society based similarity of species content," K. Danske. Videns. Selsk. 5: 1-34.

Sorensen, T.A. (1948). A method of establishing groups of equal amplitude in plant sociology based on similarity of species content, and its application to analyses of the vegetation on Danish commons. Kgl Danske Vidensk. Selsk. Biol. Skr., 5: 1-34.

Tenkouano, A., and Baiyeri, K.P. (2007). Adoption Pattern and Yield Stability of Banana and Plantain Genotypes grown in Contrasting Agro- ecology zone in Nigeria. African Crop Science Conference Proceedings. 8:, 377-384

Wolda, H. (1983). Diversity, diversity indices and tropical cockroaches Ecologica Journal 58: 290-298. 